\title{
The Effects of Smart Factory Operational Strategies and System Management on the Innovative Performance of Small- and Medium-Sized Manufacturing Firms
}

\author{
Rok Lee (D)
}

check for updates

Citation: Lee, R. The Effects of Smart Factory Operational Strategies and System Management on the Innovative Performance of Small- and Medium-Sized Manufacturing Firms. Sustainability 2021, 13, 3087.

https://doi.org/10.3390/su13063087

Academic Editor: Roberta Costa

Received: 12 February 2021

Accepted: 5 March 2021

Published: 11 March 2021

Publisher's Note: MDPI stays neutral with regard to jurisdictional claims in published maps and institutional affiliations.

Copyright: (C) 2021 by the author. Licensee MDPI, Basel, Switzerland. This article is an open access article distributed under the terms and conditions of the Creative Commons Attribution (CC BY) license (https:// creativecommons.org/licenses/by/ $4.0 /)$.
Department of LINC Plus Project Organization, Gyeongsang National University, Jinju 52828, Korea; roklee@gnu.ac.kr; Tel.: +82-10-6314-4004

\begin{abstract}
This study aims to determine the effects of smart factory system management and operational strategies on the innovative performance of small- and medium-sized manufacturing firms. To this end, we administered an empirical survey to 222 hands-on workers who operate smart factories in small- and medium-sized Korean firms. The collected data were analyzed using structural equation modeling and the results showed that the enterprise resource planning (ERP), quality management, ethical management, and productivity management systems had positive effects on innovative performance. The effect of operational strategies on innovative performance was not verified. Consequently, small- and medium-sized firms should focus on establishing ERP systems, which lead to system establishment, standardization of work processes, CEO support and attention, and increase user recognition levels for raising innovative performance.
\end{abstract}

Keywords: smart factory; strategy; innovation performance; Korea

\section{Introduction}

Workers in smart factory environments monitor the production line and, based on recorded data, perform operational management tailored to the productivity and efficiency of manufacturing the best products with the least resources. In particular, the introduction of information and communications technology (ICT) allows for quick and accurate support, and the central system of the smart factory saves time and expenses from product distribution to product release. There is a growing trend to build smart factories at the private level [1].

Such systems can be successfully built and operated by ICT when organizations integrate technology and management to create efficient system management through the adoption of smart factories. Specifically, the central government in Korea has been focusing on the adoption of 20,000 smart factories by 2022, pushing the smartification of manufacturing factories forward in a drive toward "manufacturing innovation strategies [2]".

However, although small- and medium-sized enterprises (SMEs) recognize the need to introduce smart factory systems, they are concerned about investment due to the lack of expertise regarding their introduction and cost and the technology in relation to the limited abilities of the suppliers [3].

The integration of operational strategies with the introduction of smart factories and smart factory system management in manufacturing, which will enable flexible production through the establishment and application of digital technologies in the wake of the Fourth Industrial Revolution, is recognized as inevitable. These changes provide opportunities to create new products and new business models based on data from production and sales processes [4-6].

In other words, the introduction of smart factory operational strategies and system management is inevitable, especially for SMEs aiming to become large corporations. To this end, countries such as Germany, the U.S., Japan, and China are introducing competitive 
"manufacturing innovation strategies" for increasing the competitiveness of the manufacturing industry by applying digital technologies to manufacturing sites to satisfy the growing demand for smart manufacturing. This process uses digital elements from the production stage for the advancement of product characteristics and hardware types to promote embedded software and service convergence [7].

This is also an opportunity to reinvent manufacturing in Korea, as the country has come to a new understanding of the importance of SME strategic management for stable economic growth since the 2008 global financial crisis. The Fourth Industrial Revolution Committee [8] manages a high proportion of the manufacturing industry in Korea and has pointed out that there is a high risk of losing competitiveness. As such, the introduction of smart factory operation strategies and system managements was discussed as an alternative to improve innovative performance. In this study, we considered innovative performance as a dependent variable.

Further, we conjectured that enterprise resource management (ERP), quality management, ethical management, and productivity management in the manufacturing industry can improve corporate innovation performance because it is influenced by the inherent system management [9-13].

This study aims to identify the effects of smart factory system management and operational strategies, which are characteristic of Korea's SME manufacturing innovation strategies, on innovation performance by conducting an empirical survey and identifying interdisciplinary development measures and practical industry implications [14].

This study is structured as follows. Sections $2-5$ cover the theoretical background, research design, results and discussion, and conclusions of the analysis, respectively.

\section{Theoretical Background}

\subsection{Operational Strategy of a Smart Factory}

The operational strategies of a smart factory can be largely summarized as facility and business automation, along with the integration of internal and external resources. The basis for the operation of a smart factory begins with automating the partial or full production of existing manufacturing facilities and connecting production facilities [15]. Wiktorsson et al. [16] stated that facility automation means unmanned facility operation through the replacement of human labor with robots or machines.

Here, facility and business automation as an operational strategy is an essential factor and affects production efficiency (as an increase) and costs (as a reduction). Additionally, it provides competitive advantages, such as rapid responses to new product development, retention of product quality and a reduction in defect rates, retention of work safety, and production reflecting customer needs.

For SMEs with insufficient resource capabilities, the integration of internal and external resources can improve competitiveness, leading to corporate innovation, which becomes a driving force for growth and development. In particular, the strategy of using government support is representative of the external operational resources of SMEs and an important factor for the successful operation of smart factories.

Therefore, this study measures and analyzes facility and business automation and the integration of internal and external resources as operational strategies for the introduction of a smart factory.

\subsection{System Management}

System management refers to a real-time management method for actively coping with environmental changes and increasing performance through the integration of systemic thinking into management activities to achieve the management goals of a successful company.

In this sense, system management is a highly efficient, autonomous management system that improves competitiveness by enhancing and then maintaining continuity to link the planning, execution, and evaluation phases systematically while also systematiz- 
ing each step. It is thus an efficient management system that improves productivity by systematically standardizing and systematizing business processes [17]. There are several studies on management systems as key determinants of innovation performance [18-20].

Companies are introducing ERP systems into system management to redesign their organizational structures and innovate their information systems in response to the rapidly changing business environment. ERP is not simply a tool for establishing an information system but is accepted as part of management innovation that continuously transforms the corporate organization based on management strategies in response to changes in the business environment [21]. It also improves the reliability and efficiency of information through the unified management of business processes and data across the enterprise and helps dramatically improve management speed and productivity by identifying corporate business status in real time [22].

Under a systemic approach, the quality innovation of an organization, from product design to production and sales activities, represents the quality management system [23]. A quality management system is a systematic management basis for companies to increase innovation activities at the enterprise level based on quality management [1]. As it can satisfy the needs of customers by improving the product and quality level of a company as well as playing an important role in improving corporate competitiveness, process-oriented system management is required to satisfy customer demand [19]. An ethical management system refers to a reasonable system that is integrated and constructed so that a management program can efficiently achieve the goals and objectives of ethical management in connection with the existing management system within the organization [24]. A productivity management system refers to a management system that improves productivity by examining the productivity level and capability of the management system to increase corporate productivity [25]. It has the main purpose of designing and implementing a realizable management system through which a company can improve innovative performance.

Therefore, this study measures the management of smart factory systems for manufacturing SMEs by considering ERP, quality, ethical, and productivity management.

\subsection{Smart Factory Operation Strategy and Innovative Performance in SMEs}

There are several empirical studies on the effects of overall smart factory operation strategies on innovation performance in companies in Korea and other countries. For instance, Yam et al. [26] empirically verified the relationship between smart factory operation strategies and innovation performance in 213 innovative manufacturers in Beijing, China. Specifically, these researchers studied whether smart factory operation strategies affect the innovation performance of SMEs and showed that the effects of individual operation strategies related to each innovation performance type on innovation performance varied by company size-large, medium, or small. Although smart factory operation strategies affect all manufacturing SMEs in terms of innovation rate and performance, resource allocation showed significant results only for small companies. The frequency analysis of individual innovation performance further showed that R\&D and resource allocation competences, R\&D and strategic planning competences, and resource allocation and marketing competences were significant for large companies, medium companies, and SMEs, respectively.

Aghajari and Senin [27] studied Malaysian manufacturing SMEs whose operational strategies deliver innovative market outcomes, the core of which is a strategic mindset. This strategic mindset and the innovative actions of companies' management achieved operational and financially desirable results.

Lee and Jung [28] empirically determined the direct and indirect effects of technology innovation smart factory strategies and technology commercialization capabilities on management innovation performance using the mediating role of market information orientation for 183 Inno-Biz companies in Korea. They measured smart factory operation capabilities and innovation performance by dividing the former into three categories: production, marketing, and commercialization capabilities. Their results can be summarized 
as follows. First, smart factory operation strategies had a positive effect on innovation performance, while regular operation strategies did not have a significant effect on innovation performance. Second, technology commercialization capabilities also had a positive overall effect on innovation performance. These results indicate that, as a result of the nature of Inno-Biz companies, innovative performance is not dependent on smart factory operation strategies but, rather, is improved only when their technological base and organizational management are efficiently integrated and operated. In developing new products and technologies, the most important aspect is the technological base. Consequently, smart factory operation strategies in manufacturing SMEs will affect innovation performance.

\subsection{System Management and Innovative Performance of SMEs}

Maas et al. [13] identified the role of ERP on organizational innovation and highlighted its importance. Karim et al. [12] stated that the scope of ERP implementation has a positive effect on business process outcomes, given ERP's substantial benefits. Xie et al. [11] surveyed China's banking companies and determined that the threat of corruption has a positive effect on new product innovation and that policy instability and competition positively improve the relationship between corruption and new product innovation. Additionally, Shafique et al. [29] suggested that ethical leadership directly influences creativity and organizational innovation, thus suggesting that business ethics are an important determinant of innovation performance.

Therefore, continuous efforts to establish quality corporate cultures through systemic approaches and process management systems are needed to improve quality levels through quality management activities [30], while process-oriented system management is necessary to provide quality at the level required by customers [19]. It is also necessary to build an ethical management system that provides excellent human resources and organizational members with ethical and moral qualities, which are basic elements of an ethical management system [20].

The scientific analysis of various determinants of corporate management and their systematic integration into management activities from the comprehensive perspective of system formation will significantly contribute to management innovation and enhance the competitiveness of SME ventures [31].

As customer demand diversifies due to the rapidly changing market environment, SME environmental management is negatively affected by the reduced product life cycle and expectations for high quality at low costs. These developments have highlighted the importance of management innovation to secure a competitive advantage in the market. If there is no innovation, the competitive advantage of a firm can be imitated and will eventually have to rely on price competition over products or services, which has become commonplace [6,32].

A company's performance over a specific period determines the success of its management. In general, performance is measured by financial performance (e.g., sales, market share, net profit growth) and non-financial performance (e.g., customer satisfaction, productivity improvement, defect reduction) [33,34].

In the study of performance, innovation performance is closely related to corporate system management, which includes the achievement of organizational goals, the capability to exploit the environment for resource acquisition, adapt to and survive the changing environment, develop human resources and satisfy the needs of organizational members, and remain productive and profitable [35]. Therefore, this study aims to identify the relationship between system management and innovation performance in SMEs.

\section{Research Design}

\subsection{Research Model}

As previously mentioned, the purpose of this study was to determine the empirical effects of smart factory operation strategies and system management on the innovation performance of SMEs based on constructs from previous studies. The independent variables 
are the ERP, quality management, ethical management, and productivity management systems, which are also components of the smart factory operation strategy and system management, while the dependent variable is represented by innovation performance. These variables were analyzed using a structural equation model using the AMOS program, as per Figure 1.

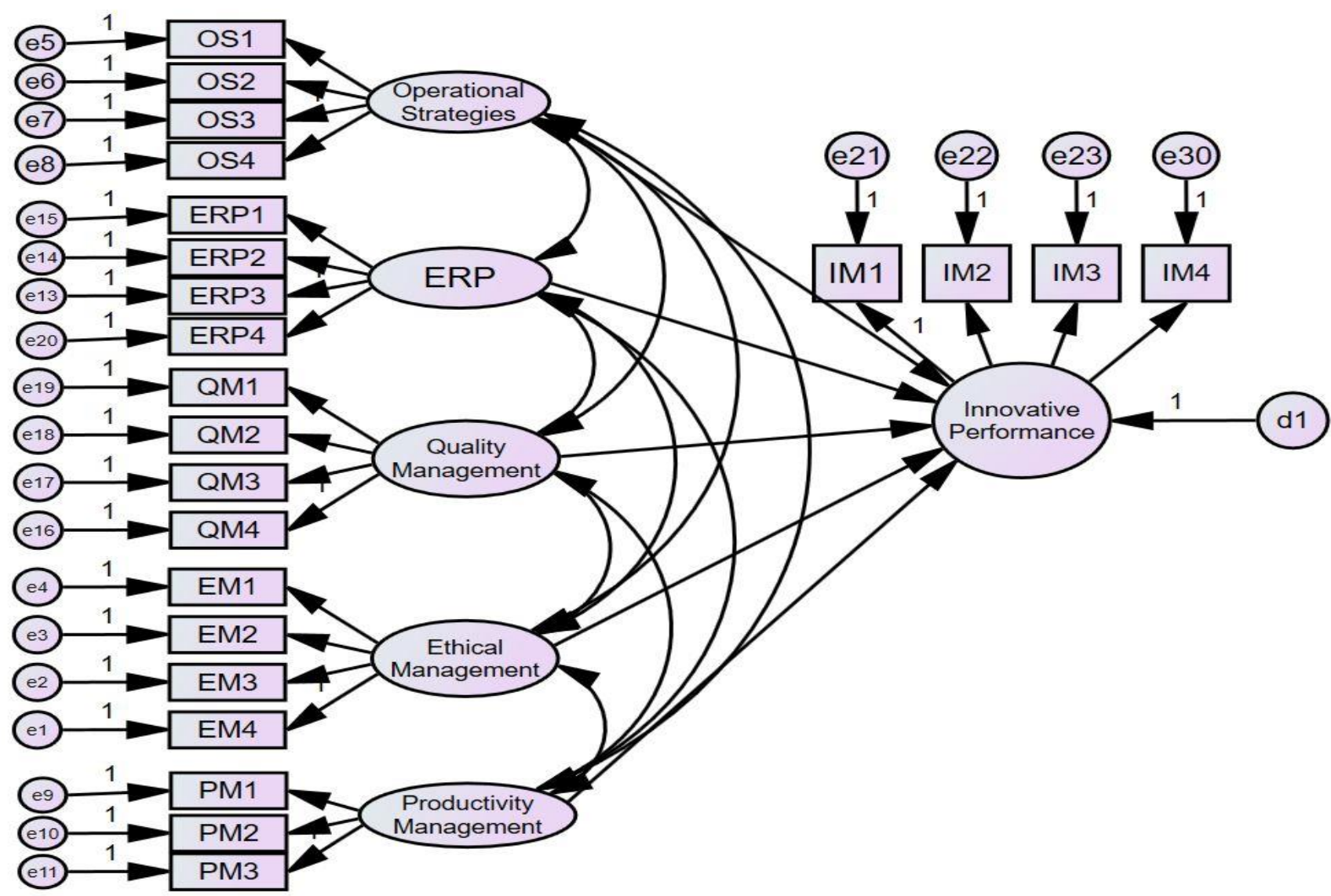

Figure 1. Research model.

\subsection{Questionnaire}

Table 1 shows the operational definitions of the variables and the composition of the questionnaire. The survey was conducted with hands-on workers in charge of introducing and operating SME smart factories in Korea. The survey period was from 18 May to 12 June 2020, and a structured questionnaire was used. A total of 260 questionnaires were distributed and 222 valid responses were used for the final analysis, after excluding 38 questionnaires with false or missing values. The questionnaire items were measured on a five-point Likert scale and the general characteristics were measured on a nominal scale. Please also see the Appendix A. Questionnaire. 
Table 1. Questionnaire structure.

\section{Variable}

Operational strategy
(1) Operational Definition
No. of Items

(2) Source

\begin{tabular}{|c|c|c|c|c|}
\hline \multicolumn{2}{|c|}{ Operational strategy } & $\begin{array}{l}\text { A strategy for the automation of } \\
\text { business and production operation by } \\
\text { using manufacturing facilities and } \\
\text { data and the integration of resources }\end{array}$ & 4 & [15] \\
\hline \multirow{4}{*}{ System Management } & ERP & $\begin{array}{l}\text { A system that enables in-service } \\
\text { workers and top managers to integrate } \\
\text { and manage corporate resources } \\
\text { efficiently and manage corporate } \\
\text { resources and facilities }\end{array}$ & 4 & {$[36,37]$} \\
\hline & $\begin{array}{l}\text { Quality/System } \\
\text { management }\end{array}$ & $\begin{array}{l}\text { A system that aims to improve the } \\
\text { product quality and management } \\
\text { balance by improving the corporate } \\
\text { management system through a } \\
\text { systematic approach }\end{array}$ & 4 & {$[32,38,39]$} \\
\hline & Ethical management & $\begin{array}{l}\text { An integrated system in which the } \\
\text { ethical management program can be } \\
\text { linked with other existing systems in a } \\
\text { company to achieve ethical } \\
\text { management goals and objectives }\end{array}$ & 4 & {$[5,24]$} \\
\hline & $\begin{array}{l}\text { Productivity } \\
\text { management }\end{array}$ & $\begin{array}{l}\text { A management system to improve } \\
\text { productivity }\end{array}$ & 3 & [25] \\
\hline \multicolumn{2}{|c|}{ Innovative performance } & $\begin{array}{l}\text { Quality and performance for price, } \\
\text { release frequency of new products, } \\
\text { and level of intellectual } \\
\text { property rights }\end{array}$ & 4 & [26] \\
\hline \multicolumn{2}{|c|}{ General information } & $\begin{array}{l}\text { Industry type, number of workers, } \\
\text { sales, positions }\end{array}$ & 4 & \\
\hline \multicolumn{3}{|c|}{ Total } & 27 & \\
\hline
\end{tabular}

\subsection{Reliability and Validity Analyses}

Table 2 shows the reliability and validity of each variable. The smart factory operation strategy had a Cronbach's $\alpha$ indicating the reliability and validity of each variable. The smart factory operational strategies, system management, innovative performance in a company aims to achieve this, thus, satisfying validity requirements [40].

The ERP, quality management, ethical management, and productivity management as sub-factors of system management had Cronbach's $\alpha$ values of 0.7 or higher, indicating satisfactory reliability. The factor analysis of validity showed that the Kaiser-Meyer-Olkin test $(\mathrm{KMO})$ value as a single factor exceeded 0.6 for all sub-factors. Innovation performance also had a Cronbach's $\alpha$ indicating satisfactory reliability. The reliability and the KMO value as a single factor exceeded 0.6 for each sub-factor. The factors were thus used for analysis without any modifications. 
Table 2. Results of the validity and reliability tests.

\begin{tabular}{|c|c|c|c|c|c|c|c|}
\hline \multicolumn{3}{|c|}{ Factor } & $\begin{array}{c}\text { Factor } \\
\text { Loading }\end{array}$ & $\begin{array}{l}\text { Eigen } \\
\text { Value }\end{array}$ & $\begin{array}{c}\text { Variance } \\
(\%)\end{array}$ & $\mathrm{KMO}^{1}$ & $\begin{array}{c}\text { Cronbach's } \\
\alpha\end{array}$ \\
\hline \multirow{4}{*}{\multicolumn{2}{|c|}{ Operational strategies }} & OS1 & 0.814 & \multirow{4}{*}{3.173} & \multirow{4}{*}{79.328} & \multirow{4}{*}{0.825} & \multirow{4}{*}{0.912} \\
\hline & & OS2 & 0.926 & & & & \\
\hline & & OS3 & 0.933 & & & & \\
\hline & & OS4 & 0.884 & & & & \\
\hline \multirow{15}{*}{$\begin{array}{c}\text { System } \\
\text { Management }\end{array}$} & \multirow{4}{*}{$\mathrm{ERP}^{2}$} & ERP1 & 0.827 & \multirow{4}{*}{2.524} & \multirow{4}{*}{63.101} & \multirow{4}{*}{0.792} & \multirow{4}{*}{0.804} \\
\hline & & ERP2 & 0.802 & & & & \\
\hline & & ERP3 & 0.793 & & & & \\
\hline & & ERP4 & 0.754 & & & & \\
\hline & \multirow{4}{*}{$\begin{array}{c}\text { Quality } \\
\text { management }\end{array}$} & QM1 & 0.828 & \multirow{4}{*}{2.553} & \multirow{4}{*}{63.837} & \multirow{4}{*}{0.765} & \multirow{4}{*}{0.836} \\
\hline & & QM2 & 0.799 & & & & \\
\hline & & QM3 & 0.804 & & & & \\
\hline & & QM4 & 0.763 & & & & \\
\hline & \multirow{4}{*}{$\begin{array}{c}\text { Ethical } \\
\text { management }\end{array}$} & EM1 & 0.670 & \multirow{4}{*}{2.713} & \multirow{4}{*}{67.833} & \multirow{4}{*}{0.790} & \multirow{4}{*}{0.835} \\
\hline & & EM2 & 0.887 & & & & \\
\hline & & EM3 & 0.870 & & & & \\
\hline & & EM4 & 0.849 & & & & \\
\hline & \multirow{3}{*}{$\begin{array}{l}\text { Productivity } \\
\text { management }\end{array}$} & PM1 & 0.806 & \multirow{3}{*}{1.957} & \multirow{3}{*}{65.247} & \multirow{3}{*}{0.685} & \multirow{3}{*}{0.733} \\
\hline & & PM2 & 0.798 & & & & \\
\hline & & PM3 & 0.819 & & & & \\
\hline \multirow{4}{*}{\multicolumn{2}{|c|}{ Innovative performance }} & IP1 & 0.770 & \multirow{4}{*}{2.568} & \multirow{4}{*}{64.197} & \multirow{4}{*}{0.774} & \multirow{4}{*}{0.811} \\
\hline & & IP2 & 0.792 & & & & \\
\hline & & IP3 & 0.823 & & & & \\
\hline & & IP4 & 0.819 & & & & \\
\hline
\end{tabular}

${ }^{1}$ KMO: Kaiser-Meyer-Olkin test; ${ }^{2}$ ERP: enterprise resource management.

\subsection{Hypotheses Development}

System management can improve the reliability and efficiency of information by the unified management of business processes and data, increase management speed and productivity by understanding the corporate management status in real time, and promote quality innovation from product design to production and sales activities. Such system management is adopted to actively cope with rapid environmental changes and strengthening competitiveness. As a result, simultaneous changes in organizational structure, strategy, organizational culture, and management technique are promoted for the constitution of the entire organization [41].

An empirical analysis of the differences before and after the introduction of an ERP system using financial data from companies showed that the system had a positive effect on financial and operating performance [42]. Jung and Jung [37] conducted research on companies that had introduced and used the ERP system for more than one year, showing that the system had a positive effect on both financial and non-financial performance.

Kim and Jang [43] showed that quality management activities had a positive effect on financial performance such as operating earnings, market share, earnings rate, and sales in corporate management. Additionally, companies can achieve economic performance while fulfilling their ethical responsibilities [44] and actively practicing ethical management activities. In other words, ethical management can improve corporate competitiveness. 
Further, Purwanto et al. [45] stated that the productivity management system had a significant effect on management performance, while Prakash et al. [46] conducted an empirical analysis of the relationship between the productivity management system and productivity management performance, showing that the former had a positive effect on the latter.

In accordance with these prior studies, the introduction and use of ERP systems, quality management, ethical management, and productivity management could be expected to affect innovation performance:

Hypothesis 1. A smart factory operation strategy will have a significant effect on innovation performance.

Hypothesis 2. Smart factory system management will have a significant effect on innovation performance.

Hypothesis 2-1. The ERP for smart factory system management will have a significant effect on innovation performance.

Hypothesis 2-2. Quality management in smart factory system management will have a significant effect on innovation performance.

Hypothesis 2-3. Ethical management in smart factory system management will have a significant effect on innovation performance.

Hypothesis 2-4. Productivity management in smart factory system management will have a significant effect on innovation performance.

\subsection{Data}

Table 3 shows the characteristics of companies whose employees responded to the questionnaire. By industry, these were 40 electric, electronics, semiconductor, and telecommunications companies (18.0\%); 45 heavy equipment and auto parts companies (20.3\%); 40 farm machinery and marine engine parts companies (18.0\%); 28 metal and machinery companies (12.6\%); and 69 other companies (31.1\%). There were less than 50 employees in 22 companies (9.9\%), 51-100 in 71 companies (32.0\%), 101-200 in 115 companies $(51.8 \%)$, and more than 201 in 14 companies (6.3\%). Regarding sales volumes, 64 companies (28.8\%), 42 companies $(18.9 \%), 53$ companies $(23.9 \%), 28$ companies $(12.6 \%)$, and 35 companies (15.8\%) had sales of less than KRW 5 billion, 5.1-7.0 billion, 7.1-12.0 billion, 12.1-20 billion, and above 20.1 billion, respectively. The positions of respondents showed that $139(62.6 \%)$, $48(21.6 \%), 22(9.9 \%)$, and $13(5.9 \%)$ were below the Deputy Section Head, Section Head and Deputy Department Head, Department Head, and Executive and other, respectively. 
Table 3. General characteristics of the respondents.

\begin{tabular}{|c|c|c|c|}
\hline General Information & General Information & Frequency (N) & Percentage (\%) \\
\hline \multirow{5}{*}{ Industry } & $\begin{array}{l}\text { Electricity, electronics, } \\
\text { semiconductor, } \\
\text { telecommunications }\end{array}$ & 40 & 18.0 \\
\hline & Heavy equipment, auto parts & 45 & 20.3 \\
\hline & $\begin{array}{l}\text { Farm machinery, marine } \\
\text { engine parts }\end{array}$ & 40 & 18.0 \\
\hline & Metal machinery & 28 & 12.6 \\
\hline & Other & 69 & 31.1 \\
\hline \multirow{4}{*}{ Number of workers } & Below 50 & 22 & 9.9 \\
\hline & $51-100$ & 71 & 32.0 \\
\hline & $101-200$ & 115 & 51.8 \\
\hline & Above 201 & 14 & 6.3 \\
\hline \multirow{5}{*}{ Sales } & Below KRW 5 billion & 64 & 28.8 \\
\hline & KRW 5.1-7.0 billion & 42 & 18.9 \\
\hline & KRW 7.1-12 billion & 53 & 23.9 \\
\hline & KRW 12.1-20 billion & 28 & 12.6 \\
\hline & Above KRW 20.1 billion & 35 & 15.8 \\
\hline \multirow[t]{4}{*}{ Position } & Below Deputy Section Head & 139 & 62.6 \\
\hline & $\begin{array}{l}\text { Section Head, Deputy } \\
\text { Department Head }\end{array}$ & 48 & 21.6 \\
\hline & Department Head & 22 & 9.9 \\
\hline & Executive and other & 13 & 5.9 \\
\hline \multirow{2}{*}{ Gender } & Male & 198 & 89.2 \\
\hline & Female & 24 & 10.8 \\
\hline \multirow{4}{*}{ Age } & Thirties & 48 & 21.6 \\
\hline & Forties & 129 & 58.1 \\
\hline & Fifties & 32 & 14.4 \\
\hline & Sixties & 13 & 5.9 \\
\hline \multicolumn{2}{|c|}{ Total } & 222 & 100 \\
\hline
\end{tabular}

\section{Results}

\subsection{Confirmatory Factor Analysis}

The confirmatory factor analysis was conducted using IBM SPSS 25 and AMOS 25 to identify the validity of the research model as explained by the measurement variables and to determine the overall goodness of the model fit. We obtained Chi-square $=383.220$, degrees of freedom $=287$, goodness of fit index RMSEA $=0.039, \mathrm{RMR}=0.048, \mathrm{AGFI}=0.903$, $\mathrm{GFI}=0.919, \mathrm{CFI}=0.974$, which were above the minimum required values (i.e., AGFI, GFI, and CFI of 0.9 or above and RMR of 0.05 below show model fitness) [47].

The construct reliability (CR) and average variance extracted (AVE) were calculated to verify convergent validity. Convergent validity should satisfy a standardized factor load of 0.5 or more, a t-value of 1.965 or more, an AVE of 0.5 or more, and a construct reliability of 0.7 or more. Table 4 shows the results of the confirmatory factor analysis and convergent validity, in which all variables satisfy the validity criteria. 
Table 4. Results of the confirmatory factor analysis and convergent validity.

\begin{tabular}{|c|c|c|c|c|c|c|c|c|}
\hline \multicolumn{3}{|c|}{ Variable } & B & $\beta$ & S.E. & C.R. & $\mathrm{CR}^{1}$ & $\mathrm{AVE}^{2}$ \\
\hline \multirow{4}{*}{\multicolumn{2}{|c|}{ Operational strategy }} & OS1 & 0.787 & 0.743 & 0.055 & 14.363 & \multirow{4}{*}{0.893} & \multirow{4}{*}{0.678} \\
\hline & & OS2 & 0.966 & 0.908 & 0.044 & 22.127 & & \\
\hline & & OS3 & 1 & 0.925 & - & - & & \\
\hline & & OS4 & 0.854 & 0.842 & 0.046 & 18.447 & & \\
\hline \multirow{8}{*}{\multicolumn{2}{|c|}{$\begin{array}{c}\text { System } \\
\text { Management }\end{array}$}} & ERP1 & 0.898 & 0.648 & 0.106 & 8.466 & \multirow{4}{*}{0.823} & \multirow{4}{*}{0.538} \\
\hline & & ERP2 & 1.057 & 0.788 & 0.106 & 9.927 & & \\
\hline & & ERP3 & 0.95 & 0.709 & 0.104 & 9.166 & & \\
\hline & & ERP4 & 1 & 0.704 & - & - & & \\
\hline & & QM1 & 0.881 & 0.69 & 0.093 & 9.519 & 0.846 & 0.580 \\
\hline & & QM2 & 1.164 & 0.803 & 0.106 & 10.948 & & \\
\hline & & QM3 & 1 & 0.731 & - & - & & \\
\hline & & QM4 & 1.117 & 0.782 & 0.104 & 10.703 & & \\
\hline \multirow{4}{*}{\multicolumn{2}{|c|}{$\begin{array}{c}\text { Ethical } \\
\text { management }\end{array}$}} & EM1 & 0.759 & 0.56 & 0.089 & 8.491 & 0.844 & 0.581 \\
\hline & & EM2 & 1.064 & 0.822 & 0.078 & 13.64 & & \\
\hline & & EM3 & 1.082 & 0.838 & 0.077 & 13.994 & & \\
\hline & & EM4 & 1 & 0.815 & - & - & & \\
\hline \multirow{3}{*}{\multicolumn{2}{|c|}{$\begin{array}{l}\text { Productivity } \\
\text { management }\end{array}$}} & PM1 & 1.211 & 0.743 & 0.136 & 8.9 & 0.774 & 0.535 \\
\hline & & PM2 & 0.888 & 0.598 & 0.117 & 7.571 & & \\
\hline & & PM3 & 1 & 0.718 & - & - & & \\
\hline \multirow{4}{*}{\multicolumn{2}{|c|}{ Innovation performance }} & IP1 & IP1 & 0.659 & 0.096 & 9.421 & 0.856 & 0.600 \\
\hline & & IP2 & IP2 & 0.705 & 0.08 & 10.107 & & \\
\hline & & IP3 & IP3 & 0.777 & - & - & & \\
\hline & & IP4 & IP4 & 0.749 & 0.082 & 10.755 & & \\
\hline
\end{tabular}

${ }^{1} \mathrm{CR}$ : construct reliability; ${ }^{2}$ AVE: average variance extracted; ${ }^{3}$ ERP: enterprise resource management.

\subsection{Discriminant Analysis}

Table 5 shows the squared values of the correlation between two variables to verify the results of discriminant validity. It can be said that there is discriminant validity when the value of AVE is larger than the square of the correlation between two variables. In Table 3, the AVE value satisfied the tolerance value of 0.5 for all variables and most of the correlation squared values were lower than 0.5 when compared with Table 4 , satisfying the discriminant validity criterion.

\subsection{Path Analysis}

The goodness of fit index of the research model can be summarized as follows: Chisquare $=401.040$, degrees of freedom $=287$, AGFI $=0.903, \mathrm{GFI}=0.919, \mathrm{CFI}=0.969$, RMSEA $=0.042$, and RMR $=0.048$. Therefore, the model fit is acceptable. Table 6 shows the results of the structural equation model. 
Table 5. Correlation coefficient square values.

\begin{tabular}{cccccc}
\hline Variable & ERP ${ }^{1}$ & $\begin{array}{c}\text { Quality } \\
\text { Management }\end{array}$ & $\begin{array}{c}\text { Ethical } \\
\text { Management }\end{array}$ & $\begin{array}{c}\text { Productivity } \\
\text { Management }\end{array}$ & $\begin{array}{c}\text { Innovation } \\
\text { Performance }\end{array}$ \\
\hline Operational strategy & 0.242 & 0.319 & 0.456 & 0.441 & 0.253 \\
\hline ERP & 1 & 0.268 & 0.376 & 0.144 & 0.232 \\
\hline $\begin{array}{c}\text { Quality management } \\
\text { Ethical management }\end{array}$ & 1 & 0.408 & 0.433 & 0.319 \\
\hline $\begin{array}{c}\text { Productivity } \\
\text { management }\end{array}$ & & 1 & 0.465 \\
\hline
\end{tabular}

${ }^{1}$ ERP: enterprise resource management.

Table 6. Results of the structural equation model.

\begin{tabular}{|c|c|c|c|c|c|c|c|}
\hline & Path & & B & B & S.E. & C.R. & $p$ \\
\hline $\begin{array}{l}\text { Operational } \\
\text { strategies }\end{array}$ & $\rightarrow$ & $\begin{array}{l}\text { Innovation } \\
\text { performance }\end{array}$ & 0.007 & 0.013 & 0.036 & 0.189 & 0.85 \\
\hline ERP & $\rightarrow$ & \multirow{4}{*}{$\begin{array}{l}\text { Innovation } \\
\text { performance }\end{array}$} & 0.358 & 0.433 & 0.075 & 4.785 & $* * *$ \\
\hline $\begin{array}{c}\text { Quality } \\
\text { management }\end{array}$ & $\rightarrow$ & & 0.128 & 0.18 & 0.053 & 2.425 & $0.015^{*}$ \\
\hline $\begin{array}{c}\text { Ethical } \\
\text { management }\end{array}$ & $\rightarrow$ & & 0.303 & 0.394 & 0.064 & 4.731 & $* * *$ \\
\hline $\begin{array}{l}\text { Productivity } \\
\text { management }\end{array}$ & $\rightarrow$ & & 0.375 & 0.248 & 0.135 & 2.78 & $0.005^{* *}$ \\
\hline
\end{tabular}

${ }^{* * *} p<0.001,{ }^{* *} p<0.01,{ }^{*} p<0.05$.

In summary, Hypothesis 1 had no significant effect, with a path coefficient of 0.013 and $\mathrm{CR}=0.189, p>0.05$. Hypothesis $2-1$ had a significant effect, with a path coefficient of 0.433 and $C R=4.785, p<0.05$. Hypothesis $2-2$ had no significant effect, with a path coefficient of 0.18 and $C R=2.425, p<0.05$. Hypothesis $2-3$ had a significant effect, with a path coefficient of 0.394 and $C R=4.731, p<0.05$ ). Hypothesis $2-4$ had a significant effect, with a the path coefficient of 0.248 and $C R=2.78, p<0.05$.

\subsection{Discussion}

The abovementioned findings demonstrate that system management significantly affects performance improvement through technological innovation for the management of Korean manufacturing SMEs. First, the ERP for mature system management, which makes long-term survival possible, and the effort to improve quality, ethics, and productivity are important for the creation of innovation performance in addition to short-term profits. In other words, it is important to devote efforts to building and optimizing the core processes that meet mid-and long-term corporate goals in response to environmental changes in organizational operation strategies for achieving outstanding innovation performance goals. Second, since the focus is mainly on QCD (Quality, Cost, Delivery) -based production process improvement, discovery, and management even in productivity management, the innovation performance of productivity needs significant effort for organizational development, quality management, and innovation. As shown by the research results, the establishment of system management can support organization-wide decision making to achieve a strategic performance using a balanced perspective of short- and long-term external customers and internal operating processes, thus achieving technological innovation.

These results have implications for previous supporting studies [48,49], as they suggest that the utilization of applications, devices, and platform technologies in platform business is a mechanism to increase value creation through interactions between producers and consumers. Furthermore, the results confirm the findings of certain existing stud- 
ies and report data that explained the causal relationship between smart factory system management and innovation performance through empirical research based on statistical analysis. In addition, it can be concluded that successful smart factory strategies for technological innovation, which are emphasized in this study, are important for innovation performance [50]. On the basis of these results, first, it is necessary to raise awareness and establish a direction for the future application and development of smart factory technologies in SMEs and to promote needs markets, commercialization models, market standards, and industry linkages for ecosystem activation. Second, the establishment of a road map and the reestablishment of a master plan for promoting smart factories in order to accelerate domestic industry-university-institute studies on technology-based platforms, device technologies and software (SW) developments, and the government's policies on commercialization development promotion. Third, an integrated model of the entire process from order to shipment will have to be applied to constantly improve smart factory solutions for SMEs in the future and cultivate manufacturing innovation for smart factory technology systems.

\section{Conclusions}

The results showed that ERP, quality management, ethical management, and productivity management as part of system management had a positive effect on the innovation performance of smart factory operation strategies in SMEs, while the operation strategy had no significant effect on innovation performance. This means that ERP, quality management, ethical management, and productivity management, as part of the smart factory operation strategy of SMEs, can promote innovation performance.

These results suggest that SMEs should promote the establishment of an ERP system to implement smart factory operation strategies and system management in order to enhance innovation performance. Productivity-oriented management, such as ethical management, that prioritizes quality, while also improving innovation performance, should be practiced.

The quality management system should enhance innovation performance by setting customer satisfaction through quality innovation as a top priority when implementing process-oriented system integration to meet customer requirements and improve customer satisfaction with quality. It is also necessary to establish an ethical management system involving such things as the enactment of an ethical code, ethical training, and ethical counseling within a company. This implies that innovation results can be achieved when organization members establish and implement an ethical management process that enables them to act in accordance with ethical standards.

Additionally, it is necessary to actively promote system management by improving productivity management through the external ethical activities of the company reflected in transparent and honest corporate activities and ethical behavior toward stakeholders.

\subsection{Academic and Practical Implications for Corporate Management}

The abovementioned research results provide important industrial implications for the management of domestic small- and medium-sized manufacturing companies. First, the establishment of mature smart factory system management to make long-term survival possible in addition to ensuring short-term profits is important for the creation of innovative performances in the small- and medium-sized manufacturing industry. In particular, the reinforcement of internal system management strategies first needs to achieve outstanding innovative performance goals. This should establish the core process through which to achieve the mid- and long-term goals. Moreover, optimized efforts between the core processes should come first to respond to environmental changes. Second, as shown in the research results, production management needs more investment in the innovation performance measurement process, because it can measure and manage the innovative performance of technology management strategies including the smart factory system development beyond the main focus of QCD-based production process improvement, customer discovery, and management. 
In other words, the existing manufacturing environment of SMEs can maximize performance through their quality by analyzing and using system management for physical and environmental conditions with a system, that is, technology by application. In addition, the stable quality and suitability based on the stability of system management without errors or obstacles can improve corporate sales and competitiveness integrated with innovation performance.

\subsection{Limitations of the Research}

The results of this study have limited generalizability, as its survey sample comprised 222 hands-on workers in a smart factory operating among domestic small- and mediumsized manufacturing industries, without considering the corporate characteristics according to the operating strategy and system structure of the use variables. Therefore, further research is needed to secure representativeness through national probability samples. This would need to be expanded upon through follow-up research because it is influenced by the characteristics of each manufacturer's unique business type and capabilities in addition to smart factory operation strategies and system management factors.

Author Contributions: R.L. contributed to the design and implementation of the research, the analysis of the results, and the writing of the manuscript. The author have read and agreed to the published version of the manuscript.

Funding: This research received no external funding.

Institutional Review Board Statement: Not applicable.

Informed Consent Statement: Not applicable.

Data Availability Statement: Not applicable.

Conflicts of Interest: The authors declare no conflict of interest.

\section{Appendix A. Questionnaire}

Table A1. Operational strategy and system management.

\begin{tabular}{|c|c|c|c|c|c|c|}
\hline & Evaluation Item & $\begin{array}{l}\text { Strongly } \\
\text { Agree }\end{array}$ & Agree & Neutral & Disagree & $\begin{array}{l}\text { Strongly } \\
\text { Disagree }\end{array}$ \\
\hline \multirow{4}{*}{$\begin{array}{l}\text { Operational } \\
\text { strategy }\end{array}$} & $\begin{array}{l}\text { 1. The environmental safety of facilities } \\
\text { and systems is ensured so that } \\
\text { processes and finished products have } \\
\text { no harmful effect on the environment. }\end{array}$ & & & & & \\
\hline & $\begin{array}{l}\text { 2. The automation system for each } \\
\text { facility, process, and line of the product } \\
\text { manufacturing process is well } \\
\text { established. }\end{array}$ & & & & & \\
\hline & $\begin{array}{l}\text { 3. The automation system for each } \\
\text { facility, process, and line of the product } \\
\text { manufacturing process is well } \\
\text { established. }\end{array}$ & & & & & \\
\hline & $\begin{array}{l}\text { 4. It stores data collected from facilities } \\
\text { on a server, and uses cloud technologies } \\
\text { that share as needed. }\end{array}$ & & & & & \\
\hline
\end{tabular}


Table A1. Cont.

\begin{tabular}{|c|c|c|c|c|c|c|}
\hline & Evaluation Item & $\begin{array}{l}\text { Strongly } \\
\text { Agree }\end{array}$ & Agree & Neutral & Disagree & $\begin{array}{l}\text { Strongly } \\
\text { Disagree }\end{array}$ \\
\hline \multirow{4}{*}{ ERP } & $\begin{array}{l}\text { 5. Your firm has built an ERP system } \\
\text { infrastructure for continuous } \\
\text { maintenance. }\end{array}$ & & & & & \\
\hline & $\begin{array}{l}\text { 6. Your firm is actively using the ERP } \\
\text { system after persuading business } \\
\text { parties and stakeholders of its } \\
\text { importance. }\end{array}$ & & & & & \\
\hline & $\begin{array}{l}\text { 7. Your firm has improved work } \\
\text { efficiency by using the vendor managed } \\
\text { inventory (VMI) system. }\end{array}$ & & & & & \\
\hline & $\begin{array}{l}\text { 8. Your firm has increased productivity } \\
\text { by using the ERP system. }\end{array}$ & & & & & \\
\hline \multirow{4}{*}{$\begin{array}{l}\text { Quality/System } \\
\text { management }\end{array}$} & $\begin{array}{l}\text { 9. The CEO has a strong commitment to } \\
\text { the development, implementation, and } \\
\text { continuous improvement of the quality } \\
\text { management system. }\end{array}$ & & & & & \\
\hline & $\begin{array}{l}\text { 10. The organization determines and } \\
\text { secures the resources necessary for the } \\
\text { implementation, maintenance, and } \\
\text { continuous improvement of the quality } \\
\text { management system. }\end{array}$ & & & & & \\
\hline & $\begin{array}{l}\text { 11. The organization determines and } \\
\text { reviews customer requirements related } \\
\text { to the product, as well as determining } \\
\text { and implementing effective methods for } \\
\text { communicating with customers. }\end{array}$ & & & & & \\
\hline & $\begin{array}{l}\text { 12. The organization monitors } \\
\text { information related to the customer } \\
\text { perception as to whether the quality } \\
\text { management system meets customer } \\
\text { requirements as a measure of } \\
\text { performance. }\end{array}$ & & & & & \\
\hline \multirow{4}{*}{$\begin{array}{l}\text { Ethical } \\
\text { management }\end{array}$} & $\begin{array}{l}\text { 13. Our company has a code of ethics in } \\
\text { place to prevent corruption. }\end{array}$ & & & & & \\
\hline & $\begin{array}{l}\text { 14. The practice of punishing violations } \\
\text { after setting standards of conduct is } \\
\text { always followed. }\end{array}$ & & & & & \\
\hline & $\begin{array}{l}\text { 15. There are systems that allow } \\
\text { employees to report unethical behaviors } \\
\text { within the company. }\end{array}$ & & & & & \\
\hline & $\begin{array}{l}\text { 16. You are well informed of your } \\
\text { company's standards of ethical } \\
\text { behaviors to customers, suppliers, and } \\
\text { other organizations. }\end{array}$ & & & & & \\
\hline
\end{tabular}


Table A1. Cont.

\begin{tabular}{|c|c|c|c|c|c|c|}
\hline & Evaluation Item & $\begin{array}{l}\text { Strongly } \\
\text { Agree }\end{array}$ & Agree & Neutral & Disagree & $\begin{array}{l}\text { Strongly } \\
\text { Disagree }\end{array}$ \\
\hline \multirow{3}{*}{$\begin{array}{l}\text { Productivity } \\
\text { management }\end{array}$} & $\begin{array}{l}\text { 17. In order to improve productivity, the } \\
\text { company is carrying out activities to } \\
\text { eliminate waste in terms of processes } \\
\text { and jobs at the enterprise level. }\end{array}$ & & & & & \\
\hline & $\begin{array}{l}\text { 18. The company-wide consensus is } \\
\text { based on changes in customer demands } \\
\text { as to the necessity of productivity } \\
\text { improvement. }\end{array}$ & & & & & \\
\hline & $\begin{array}{l}\text { 19. Fair performance compensation for } \\
\text { productivity improvement is provided } \\
\text { through the consensus formed by } \\
\text { labor-management agreement. }\end{array}$ & & & & & \\
\hline
\end{tabular}

Table A2. Innovative performance.

\begin{tabular}{|c|c|c|c|c|c|c|}
\hline & Evaluation Item & $\begin{array}{l}\text { Strongly } \\
\text { Agree }\end{array}$ & Agree & Neutral & Disagree & $\begin{array}{l}\text { Strongly } \\
\text { Disagree }\end{array}$ \\
\hline \multirow[t]{4}{*}{$\begin{array}{l}\text { Innovation } \\
\text { performance }\end{array}$} & $\begin{array}{l}\text { 1. Our company's products have } \\
\text { recently improved in quality and } \\
\text { performance in relation to cost } \\
\text { compared to similar domestic } \\
\text { competitors. }\end{array}$ & & & & & \\
\hline & $\begin{array}{l}\text { 2. The price competitiveness of our } \\
\text { company's products are increasing in } \\
\text { the market. }\end{array}$ & & & & & \\
\hline & $\begin{array}{l}\text { 3. Our company has been releasing new } \\
\text { technologies and new products } \\
\text { frequently. }\end{array}$ & & & & & \\
\hline & $\begin{array}{l}\text { 4. Our company has more intellectual } \\
\text { property rights (patent rights, utility } \\
\text { model rights, etc.) for new technologies } \\
\text { or new products compared to the same } \\
\text { industry. }\end{array}$ & & & & & \\
\hline
\end{tabular}

General Information.

1. What is your gender? (1) Male (2) Female

2. How old are you? ( ) Years Old

3. What is your position in your company?

(1) Below Deputy Section Head (2) Section Head, Deputy Department Head

(3) Department Head (4) Executive and Other

4. What is your company's business area?

(1) Electricity, Electronics, Semiconductor, Telecommunications

(2) Heavy Equipment, Auto Parts (3) Farm Machinery, Marine Engine Parts

(4) Metal Machinery (5) Other

5. How many employees in your company?

(1) Below 50 (2) 51 100 (3) 101 200 (4) Above 201

6. What was the previous year's sales?

(1) Below KRW 5 billion (2) KRW 5.1-7.0 billion

(3) KRW 7.1-12 billion (4) KRW 12.1-20 billion (5) Above KRW 20.1 billion 


\section{References}

1. Kim, Y.J.; Chung, Y.B. A Study on the Effects of ISO 9001:2008 Quality Management Systems Requirement Implementation According to the Certification Motives on Management Performance: Focused on the Manufacturer in the Small Businesses. $J$. Soc. Korea Ind. Syst. Eng. 2015, 38, 1-10. [CrossRef]

2. Cho, H.J.; Seo, C.S.; Yoo, W.J. A Study on the Effects of System Management on the Management Performance in Small and Medium Venture Businesses. Korea Entrep. Soc. 2017, 12, 97-125. [CrossRef]

3. Lee, R.; Park, S.H.; Park, J.G. Key Success Factors of Business Performance: Evidence from Smart Factories in South Korea. J. Theor. Appl. Inf. Technol. 2020, 98, 3291-3301.

4. Won, J.Y.; Park, M.J. Smart Factory Adoption in Small and Medium-Sized Enterprises: Empirical Evidence of Manufacturing Industry in Korea. Technol. Forecast. Soc. Chang. 2020, 157, 120117. [CrossRef]

5. Arend, R.J. Ethics-Focused Dynamic Capabilities: A Small Business Perspective. Small Bus. Econ. 2013, 41, 1-24. [CrossRef]

6. Gandhi, S.K.; Sachdeva, A.; Gupta, A. Distributor Service Quality in Indian SMEs: A Bi-Directional Customer Perspective. Manag. Sci. Lett. 2018, 6, 335-356. [CrossRef]

7. Choi, Y.H.; Choi, S.H. A Study of Crossing the Chasm in Applying Smart Factory System for SMEs. Int. J. Pure Appl. Math. 2018, $118,469-487$.

8. Moon, H.C. A Study on the Systematization of the Technology Act for Platforming the Fourth Industrial Revolution. J. Korea Soc. Comput. Inf. 2019, 24, 163-169.

9. Damanpour, F. The Adoption of Technological, Administrative, and Ancillary Innovations: Impact of Organizational Factors. J. Manag. 1987, 13, 675-688. [CrossRef]

10. Khazanchi, S.; Lewis, M.W.; Boyer, K.K. Innovation-Supportive Culture: The Impact of Organizational Values on Process Innovation. J. Oper. Manag. 2007, 25, 871-884. [CrossRef]

11. Xie, X.; Qi, G.; Zhu, K.X. Corruption and New Product Innovation: Examining Firms' Ethical Dilemmas in Transition Economies. J. Bus. Ethics 2019, 160, 107-125. [CrossRef]

12. Karim, J.; Somers, T.M.; Bhattacherjee, A. The Impact of ERP Implementation on Business Process Outcomes: A Factor-Based Study. J. Manag. Inf. Syst. 2007, 24, 101-134. [CrossRef]

13. Maas, J.B.; van Fenema, P.C.; Soeters, J. ERP as an Organizational Innovation: Key Users and Cross-Boundary Knowledge Management. J. Knowl. Manag. 2016, 20, 557-577. [CrossRef]

14. Jung, J. The Fourth Industrial Revolution, Knowledge Production and Higher Education in South Korea. J. High. Educ. Policy Manag. 2020, 42, 134-156. [CrossRef]

15. Kim, H.; Huh, H.; Kang, J.W.; Boo, J. A Study on Factors Influencing the Introduction of Smart Factory: Focusing on Small and Medium-sized Enterprises in Korea. J. Soc. Korea Ind. Syst. Eng. 2019, 42, 252-261. [CrossRef]

16. Wiktorsson, M.; Noh, S.D.; Bellgran, M.; Hanson, L. Smart Factories: South Korean and Swedish Examples on Manufacturing Settings. Procedia Manuf. 2018, 25, 471-478. [CrossRef]

17. Lee, R.; Park, J.G.; Park, S.H. Effects of System Management on Value Creation and Global Growth in Born Startups: Focusing on Born Startups in Korea. JOItmC 2020, 6, 19. [CrossRef]

18. Ko, J.U. A Study on the Determining Factors of Building the System Management Structure for Risk Management of Growing Venture Businesses: Focused on Using the Information System. Korean Assoc. Small Bus. Stud. 2007, 10, 41-61.

19. Kim, S.K.; Shin, S.H.; Lee, Y.S.; Jung, T.Y. A Study on Establishing an ISO 9001:2000 quality management system using information technology. J. Korean Soc. Qual. Manag. 2005, 33, 13-21.

20. Santoro, G.; Vrontis, D.; Thrassou, A.; Dezi, L. The Internet of Things: Building a Knowledge Management System for Open Innovation and Knowledge Management Capacity. Technol. Forecast. Soc. Chang. 2018, 136, 347-354. [CrossRef]

21. Carvalho, H.L.; Guerrini, F.M. Reference Model for Implementing ERP Systems: An Analytical Innovation Networks Perspective. Prod. Plan. Control 2017, 28, 281-294. [CrossRef]

22. Altamony, H.; Al-Salti, Z.; Gharaibeh, A.; Elyas, T. The Relationship between Change Management Strategy and Successful Enterprise Resource Planning (ERP) Implementations: A Theoretical Perspective. Int. J. Bus. Manag. Econ. Res. 2016, 7, 690-703.

23. Hwang, K.H. Analyzing Employee's Perception about the Adoption of Six Sigma and Quality Management. Korean J. Bus. Admin. 2014, 27, 133-151.

24. Kim, M.S.; Thapa, B. Relationship of Ethical Leadership, Corporate Social Responsibility and Organizational Performance. Sustainability 2018, 10, 447. [CrossRef]

25. Park, W.J.; Park, K.H. An Empirical Study on the Influence of SME's Productivity Management System on Productivity Performance: Focusing on Auto Part Suppliers. Korean Assoc. Small Bus. Stud. 2011, 33, $23-41$.

26. Yam, R.C.M.; Guan, J.C.; Pun, K.F.; Tang, E.P.Y. An Audit of Technological Innovation Capabilities in Chinese Firms: Some Empirical Findings in Beijing, China. Res. Policy 2004, 31, 543-567. [CrossRef]

27. Aghajari, N.; Amat Senin, A. Strategic Orientation and Dual Innovative Operation Strategies: Implications for Performance of Manufacturing SMEs. Asia Pac. J. Bus. Admin. 2014, 6, 127-147. [CrossRef]

28. Lee, D.S.; Jung, R.C. A Study on the Effect of Technological Innovation Capability and Technology Commercialization Capability on Business Performance in SMEs of Korea. Korean Assoc. Small Bus. Stud. 2010, 32, 65-87.

29. Shafique, I.; Ahmad, B.; Kalyar, M.N. How Ethical Leadership Influences Creativity and Organizational Innovation. Eur. J. Innov. Manag. 2019, 23, 114-133. [CrossRef] 
30. Han, K.D.; Park, M.H. The Effect of Quality Management System on Continuous Improvement and Management Performance. Korean Bus. Educ. Rev. 2012, 27, 461-482.

31. Kim, S.J. The Competitiveness of SMEs and the Role of Industrial Engineering. Ind. Eng. Manag. Syst. 2007, 14, 8-11.

32. Pambreni, Y.; Khatibi, A.; Azam, S.M.F.; Tham, J. The Influence of Total Quality Management toward Organization Performance. Manag. Sci. Lett. 2019, 9, 1397-1406. [CrossRef]

33. Jin, S.H.; Lee, C.; Lee, J.T. An Exploratory Study on Success Factors of Management Information Systems on Systems Thinking Approach: Based on the Adoption Case of a Regional Branch of National Agricultural Cooperative Federation. J. Korean Entrep. Soc. 2016, 11, 218-238.

34. Han, S.H.; Jung, K.S.; Hong, S.P. Effect of Quality Management on the Performance: Focusing Manufacturing Companies Awarding Korean National Quality Award. J. Korean Soc. Qual. Manag. 2015, 42, 729-746. [CrossRef]

35. Drobyazko, S.; Barwińska-Małajowicz, A.; Ślusarczyk, B.; Zavidna, L.; Danylovych-Kropyvnytska, M. Innovative Entrepreneurship Models in the Management System of Enterprise Competitiveness. J. Entrep. Educ. 2019, 22, 1-6.

36. Lee, S.M. The Impact of Introduction Factors of ERP System on Introduction Decision and Management Performance. Korea Int. Acc. Rev. 2014, 53, 38-62. [CrossRef]

37. Jung, C.H.; Jung, D.H. An Empirical Study on Factors Affecting ERP Introduction Performance in Small and Medium Manufacturing Firms. Korean Bus. Educ. Rev. 2012, 27, 151-174.

38. Jin, S.H.; Lee, C.K.; Yoo, W.J. The Impact of Performance by the QMS through the Mediation of Absorptive Capacity in Manufacturing Company. J. Korean Soc. Qual. Manag. 2013, 41, 15-38. [CrossRef]

39. Putri, N.T.; Retha, F.; Sha', N.A.; Yusof, rM. Design of Quality System Documentation in Hydrotiller Production Unit as Improvement of Quality Management System in Small and Medium Enterprise. Int. J. Prod. Qual. Manag. 2016, 19, 116-138. [CrossRef]

40. Hair, J.F.; Anderson, R.E.; Tatham, R.L.; Black, W.C. Multivariate Data Analysis with Readings; Prentice Hall: Upper Saddle River, NJ, USA, 1998; pp. 207-219.

41. Park, M.H.; Lim, S.J. Effect of Innovation Activities on Business Performances: Focused on KM and TQM. Korea Int. Acc. Rev. 2013, 49, 363-386. [CrossRef]

42. Na, Y.; Jin, D.M. An Empirical Research on the Performance of ERP Implementation and the Market. Korea Account. Inf. Assoc. 2006, 24, 99-121.

43. Kim, H.J.; Jang, H.K. A Study on the Effects of Total Quality Management Core Factor on Business Performance. J. Korea Soc. Digit. Ind. Inf. Manag. 2005, 1, 71-78.

44. Wadock, S.A.; Smith, N. Corporate Responsibility Audits: Doing Well by Doing Good. MIT Sloan Manag. Rev. 2000, 41, 75-82.

45. Purwanto, A.; Asbari, M.; Santoso, P.B. Effect of Integrated Management System of ISO 9001: 2015 and ISO $22000: 2018$ Implementation to Packaging Industries Quality Performance at Banten Indonesia. J. Ilmiah MEA 2020, 4, 17-29.

46. Prakash, A.; Jha, S.K.; Prasad, K.D.; Singh, A.K. Productivity, Quality and Business Performance: An Empirical Study. Int. J. Prod. Perform. Manag. 2017, 66, 78-91. [CrossRef]

47. Fornell, C.; Larcker, D.F. Evaluating Structural Equation Models with Unobservable Variables and Measurement Error. J. Mark. 1981, 18, 39-50. [CrossRef]

48. Jeong, Y.S. Linking Algorithm between IoT devices for smart factory environment of SMEs. JCIT 2018, 8, $233-238$.

49. Parker, G.G.; Van Alstyne, M.W.; Choudary, S.P. Platform Revolution: How Networked Markets Are Transforming the Economy and How to Make Them Work for You. WW Nort. Co. 2016. [CrossRef]

50. Wang, S.; Wan, J.; Li, D.; Zhang, C. Implementing smart factory of industrie 4.0: An outlook. Int. J. Distrib. Sens. Netw. 2016, 12, 3159805. [CrossRef] 